Tersedia online di: http://ejournal-balitbang.kkp.go.id/index.php/JP
e-mail:jurnalpari@gmail.com
JURNAL PARI
Volume 6 Nomor 2 Desember 2020
p-ISSN: 2502-0730
e-ISSN : 2549-0133

\title{
PEMBUATAN SISTEM INFORMASI PREDIKSI PRODUKSI GARAM BERBASIS WEB
}

\author{
Dani Saepuloh \\ Pusat Riset Kelautan, Badan Riset dan Sumber Daya Manusia Kelautan dan Perikanan, KKP \\ Diterima tanggal : 08 Oktober 2020 Diterima setelah perbaikan : 05 Desember 2020 \\ disetujui terbit : 15 Desember 2020
}

\begin{abstract}
ABSTRAK
Penelitian ini bertujuan untuk melakukan evaluasi terhadap sistem prediksi jumlah produksi garam nasional 2018, berdasarkan pola siklus klimatologis yang berpengaruh tehadap fluktuasi jumlah produksi garam. Sistem prediksi ini mempunyai peran yang penting dalam pengelolaan garam di Indonesia. Sistem prediksi memberikan informasi dasar bagi keputusan penting dan kompetitif pada tingkat strategis stok garam nasional. Tujuan selanjutnya adalah menggambarkan karakter produksi di setiap sentra garam berdasarkan perbedaan kondisi cuaca dan aspek fisik lingkungan lainnya serta menyiapkan konsep sistem pembacaan prediksi produksi garam di beberapa sentra garam nasional yang dapat diakses oleh masyarakat umum berbasis web dan untuk menyebar luaskan dan mempermudah mengakses informasi hasil riset mengenai prediksi produksi garam dibuatlah Sistem Informasi Prediksi Produksi Garam Berbasis Web. Metode pengembangan perangkat lunak yang digunakan yaitu metode Waterfall. Pembuatan sistem informasi produksi garam berbasis web dapat memberikan informasi produksi garam kepada seluruh masyarakat maka tidak perlu datang ke pusriskel untuk mendapatkan informasi prediksi produksi garam, sehingga dihasilkan informasi yang cepat dan akurat.
\end{abstract}

\section{Kata Kunci: Produksi garam; Prediksi; Sistem informasi; Web design; Pusat Riset Kelautan}

\section{ABSTRACT}

This study aims to evaluate the prediction system for the amount of national salt production in 2018, based on the climatological cycle patterns that affect the fluctuation of the amount of salt production. This prediction system has an important role in salt management in Indonesia. The prediction system provides basic information for important and competitive decisions at the strategic level of national salt stocks. The next objective is to describe the character of production in each salt center based on differences in weather conditions and other physical environmental aspects and to prepare a concept for reading prediction systems for salt production in several national salt centers that can be accessed by the general public on a web-based basis and to disseminate and facilitate access to information on research results. Regarding the prediction of salt production, a Web-based Salt Production Prediction Information System is made. The software development method used is the Waterfall method. The creation of a web-based salt production information system can provide information on salt production to the entire community, so there is no need to come to the pusriskel to get predictive information on salt production, so that information is produced quickly and accurately.

Keywords: Salt production; Prediction; Information systems; Web design; Marine Research Center 


\section{PENDAHULUAN}

Pusat Riset Kelautan (Pusriskel) adalah salah satu unit kerja eselon II yang ada di lingkungan Badan Riset dan Sumber Daya Manusia (BRSDM), Pusriskel membawahi 3 bidang riset yaitu 1) bidang riset sumber daya laut dan kewilayahan; 2) bidang riset mitigasi adaptasi dan konservasi; dan 3) bidang riset teknologi kelautan. Pada tahun 2019 bidang riset teknologi kelautan melakukan penelitian dengan fokus riset mengenai garam. Guna untuk menyebar luaskan dan mempermudah mengakses informasi hasil riset mengenai produksi garam dibuatlah Sistem Informasi Prediksi Produksi Garam Berbasis Web.

Sistem informasi prediksi produksi garam berbasis web memungkinkan akademisi, peneliti, mahasiswa dan masyarakat luas yang ingin mengetahui informasi tentang prediksi produksi garam tidak perlu datang ke Pusriskel. Masyarakat cukup mengakses internet ke website pusriskel yang dituju. Hal ini lebih praktis karena masyarakat tidak perlu meluangkan waktu dan menyisihkan ongkos perjalanan untuk ke Pusriskel.

Sistem prediksi garam sebelumnya dilakukan dengan metode regresi linier berbasis aplikasi dekstop dengan parameter jumlah produksi tahunan yang dikeluarkan oleh dinas kelautan dan perikanan setempat (Castillio et.al. 2015).

Sistem informasi prediksi produksi garam berbasis web diharapkan dapat membantu masyarakat luas dalam memperoleh informasi yang berkaitan dengan prediksi produksi garam dan diharapkan juga akan menarik minat para peneliti untuk melakukan riset garam. Oleh karena itu penulis mencoba merancang sebuah website yang bertujuan untuk membantu menyebarkan informasi (sharing) data antara peneliti Pusriskel dan masyarakat luas.

\section{KAJIAN LITERATUR Pengertian Sistem Informasi}

Sistem informasi adalah suatu sistem di dalam organisasi yang mempertemukan kebutuhan pengolahan transaksi harian, mendukung operasi, bersifat manajerial dan kegiatan strategi dari suatu organisasi dan menyediakan pihak luar tertentu dengan laporan-laporan yang di perlukan (Jogiyanto, 2005). Sedangkan sistem merupakan sekumpulan elemen yang saling terkait atau terpadu yang dimaksudkan untuk mencapai tujuan tertentu. Sistem adalah suatu jaringan kerja dari prosedur-prosedur yang saling berhubungan, berkumpul bersama-sama untuk melakukan suatu kegiatan atau menyelesaikan suatu sasaran tertentu (Yasin, 2012).
Sistem informasi menerima masukan data, instruksi dan mengolah data sesuai dengan perintah untuk mengeluarkan hasilnya, ini merupakan sebagian dari peristiwa yang terjadi pada sistem informasi. Data diolah suatu model untuk dihasilkan menjadi informasi. Dalam sistem informasi kualitas dari suatu informasi tergantung pada tiga hal, yaitu:

\section{a. Akurat}

Informasi harus bebas dari kesalahan-kesalahan dan tidak menyesatkan. Akurat juga berarti informasi yang harus jelas mencerminkan maksudnya. Informasi harus akurat karena dari sumber informasi sampai ke penerima informasi kemungkinan banyak terjadi gangguan (noise) yang dapat merubah atau merusak informasi tersebut.

\section{b. Tepat pada waktunya}

Informasi yang datang pada penerima tidak boleh terlambat, karena informasi merupakan landasan didalam mengambil keputusan.

\section{c. Relevan}

Informasi yang mempunyai manfaat untuk pemakainya. Relevansi informasi untuk tiap-tiap orang satu dengan yang lainnya berbeda. Misalnya informasi mengenai sebab terjadinya kerusakan mesin produksi kepada akuntan perusahaan adalah kurang relevan dan akan lebih relevan bila ditunjukkan kepada ahli teknik perusahaan. Sedangkan nilai informasi dalam sistem informasi ditentukan dari dua hal, yaitu manfaat dan biaya mendapatkannya. Suatu informasi dikatakan bernilai bila manfaat lebih efektif dibandingkan biaya mendapatkannya.

\section{Web Browser}

Web browser (Kasiman, 2006) adalah program untuk menampilkan halaman yang berbentuk kode HTML. Semua halaman web ditulis dengan bahasa HTML (Hypertext Mark Up Language). Walaupun beberapa file mempunyai ekstensi yang berbeda (contoh: .html, .php, .php3), output file-file tersebut tetap HTML. HTML adalah medium yang selalu dikirimkan ke web browser baik halaman itu berupa halaman statis, sebuah script (seperti PHP), ataupun yang dibuat oleh program CGI (Common Gateway Interface).

\section{PHP}

PHP menurut (Kadir, 2008) merupakan singkatan dari Personal Home Page Hypertext Processor. PHP 
merupakan bahasa script yang ditempatkan dalam server dan diproses diserver hasilnya dikirimkan ke klien, tempat pemakainya menggunakan browser.

\section{MySQL}

MySQL (Kadir, 2008) menurut adalah salah satu jenis database server yang menggunakan SQL sebagai bahasa dasar untuk mengakses databasenya. Dengan menggunakan script PHP dan PERL Software database ini dapat berfungsi atau berjalan pada semua platform sistem operasi yang biasa digunakan (Windows, Linux, OS/2, berbagai varian Unix).

\section{CSS (Cascading Style Sheets)}

Menurut Komang Wiswakarma (2010), CSS (Cascading Style Sheets) adalah salah satu bahasa pemrograman desain web (style sheet language) yang mengontrol format tampilan sebuah halaman web yang ditulis dengan menggunakan bahasa penanda (markup language). Biasanya CSS digunakan untuk mendisain sebuah halaman HTML dan XHTML, tetapi sekarang bahasa pemrograman CSS bisa diaplikasikan untuk segala dokumen XML, termasuk SVG dan XUL. Tujuan utama CSS diciptakan adalah untuk membedakan konten dari dokumen dan tampilan dari dokumen, dengan itu pembuatan ataupun pemrograman ulang web akan lebih mudah dilakukan. Hal yang termasuk dalam desain web diantaranya adalah warna, ukuran dan formatting. Dengan adanya CSS, konten dan desain web akan mudah dibedakan, jadi memungkinkan untuk melakukan pengulangan pada tampilan-tampilan tertentu dalam suatu halaman web, sehingga akan memudahkan dalam membuat halaman web yang banyak, sehingga membuat waktu dalam membuat web jauh lebih cepat.

\section{jQuery}

Menurut Abdul Kadir (2011), jQuery merupakan salah satu pustaka yang dikembangkan dengan menggunakan JavaScript. Kehadirannya adalah untuk memudahkan penulisan kode JavaScript. Dengan menggunakan jQuery, penulisan kode JavaScript menjadi lebih sederhana (kodenya menjadi ringkas).
Selain itu, yang lebih penting lagi, pembuatan halaman web yang interaktif dan menarik menjadi jauh lebih mudah diimplementasikan daripada kalau Anda menuliskan JavaScript sendiri.

\section{Bootstrap}

Bootstrap merupakan Framework ataupun Tools untuk membuat aplikasi web ataupun situs web responsive secara cepat, mudah dan gratis. Bootstrap terdiri dari CSS dan HTML untuk menghasilkan Grid, Layout, Typography, Table, Form, Navigation, dan lainlain. Di dalam Bootstrap juga sudah terdapat jQuery plugins untuk menghasilkan komponen Ul yang cantic seperti Transitions, Modal, Dropdown, Scrollspy, Tooltip, Tab, Prover, Alert, Button, Carousel dan lainlain. Dengan bantuan Bootstrap bisa membuat responsive website dengan cepat dan mudah dan dapat berjalan sempurna pada browser-browser pupuler seperti Chrome, Firefox, Safari, Opera dan Internet Explorer.

\section{Macromedia Dreamweaver}

Dreamweaver merupakan salah satu software dari kelompok Macromedia yang banyak digunakan untuk mendesain situs web. Adapun Macromedia Dreamweaver itu sendiri adalah sebuah HTML editor professional yang berfungsi untuk mendesain secara visual dan mengelola situs web maupun halaman web (Lenawati, 2007).

\section{METODOLOGI}

Metode air terjun atau yang sering disebut metode waterfall sering dinamakan siklus hidup klasik (classic life cycle), dimana hal ini menggambarkan pendekatan yang sistematis dan juga berurutan pada pengembangan perangkat lunak, dimulai dengan spesifikasi kebutuhan pengguna lalu berlanjut melalui tahapan-tahapan perencanaan (planning), permodelan (modeling), konstruksi (construction), serta penyerahan sistem ke para pelanggan/pengguna (deployment), yang diakhiri dengan dukungan pada perangkat lunak lengkap yang dihasilkan (Pressman, 2012). Tahapan metode waterfall dapat dilihat pada Gambar 1. 


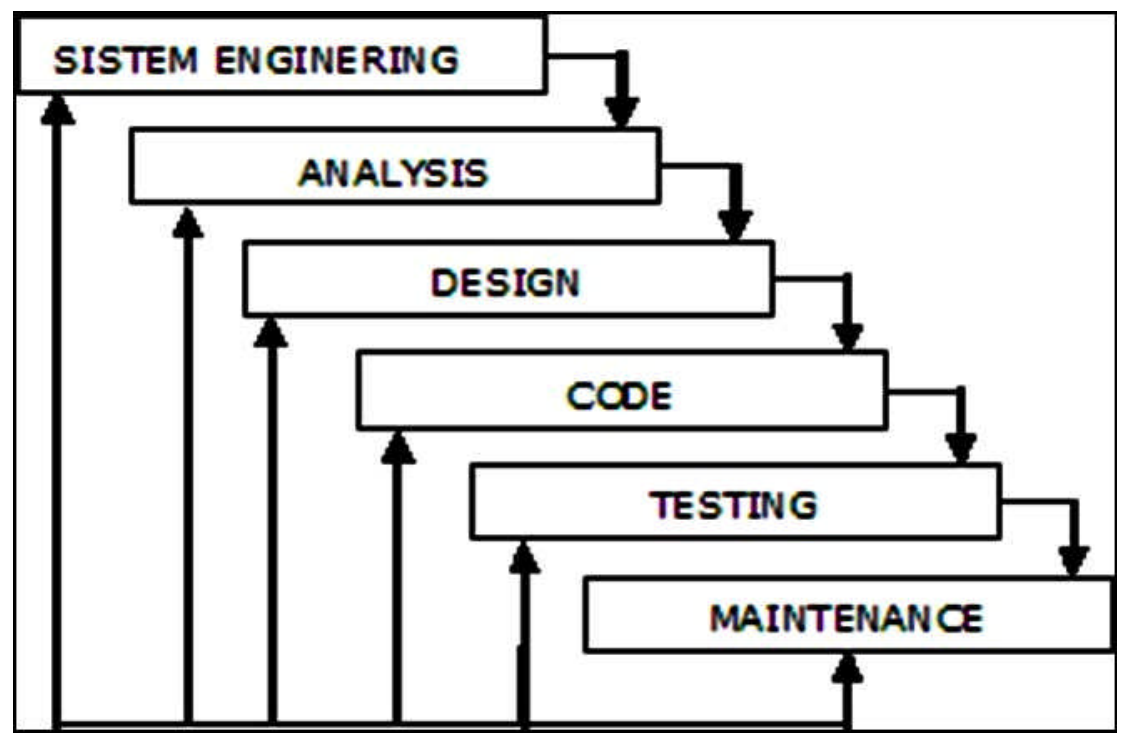

Gambar 1. Metode Waterfall.

\section{Tahapan Metode Waterfall}

Dalam pengembangannya metode waterfall memiliki beberapa tahapan yang berurut yaitu: requirement (analisis kebutuhan), design system (desain sistem), Coding (pengkodean) \& Testing (pengujian), Penerapan Program, pemeliharaan. Tahapan tahapan dari metode waterfall adalah sebagai berikut:

\section{Requirement Analisis}

Tahap ini pengembang sistem diperlukan komunikasi yang bertujuan untuk memahami perangkat lunak yang diharapkan oleh pengguna dan batasan perangkat lunak tersebut. Informasi ini biasanya dapat diperoleh melalui wawancara, diskusi atau survei langsung. Informasi dianalisis untuk mendapatkan data yang dibutuhkan oleh pengguna.

\section{System Design}

Spesifikasi kebutuhan dari tahap sebelumnya akan dipelajari dalam fase ini dan desain sistem disiapkan. Desain Sistem membantu dalam menentukan perangkat keras (hardware) dan sistem persyaratan dan juga membantu dalam mendefinisikan arsitektur sistem secara keseluruhan.

\section{Implementation}

Pada tahap ini, sistem pertama kali dikembangkan di program kecil yang disebut unit, yang terintegrasi dalam tahap selanjutnya. Setiap unit dikembangkan dan diuji untuk fungsionalitas yang disebut sebagai unit testing.

\section{Integration \& Testing}

Seluruh unit yang dikembangkan dalam tahap implementasi diintegrasikan ke dalam sistem setelah pengujian yang dilakukan masing-masing unit. Setelah integrasi seluruh sistem diuji untuk mengecek setiap kegagalan maupun kesalahan.

\section{Operation \& Maintenance}

Tahap akhir dalam model waterfall. Perangkat lunak yang sudah jadi, dijalankan serta dilakukan pemeliharaan. Pemeliharaan termasuk dalam memperbaiki kesalahan yang tidak ditemukan pada langkah sebelumnya. Perbaikan implementasi unit sistem dan peningkatan jasa sistem sebagai kebutuhan baru.

\section{Analisa Penelitian}

\section{Planning}

Merupakan rencana kerja yang matang untuk menyelesaikan suatu proyek dan disusun untuk menjalankan tahapan-tahapan seperti tahap analisis, design, dan implementasi. Dalam penulisan ini perencanaan yang dibuat penulis adalah mendefinisikan data-data yang diperlukan, menentukan sentra produksi garam mana yang akan dijadikan tempat riset, melakukan wawancara dengan petambah garam, kemudian merangkum informasi yang telah didapat.

\section{Analisis}

Merupakan tahapan kedua dalam SDLC (System Development Life Cycle). Dalam tahapan ini dideskripsikan sistem yang sedang berjalan, masalah dan kesempatan didefinisikan. Rekomendasi umum untuk bagaimana memperbaiki, meningkatkan atau mengganti sistem yang sedang berjalan diusulkan. Tujuan utama dari fase analisis adalah untuk memahami dan mendokumentasikan kebutuhan. 
Dalam kasus ini penulis membuat analisa untuk kebutuhan masukan yang dibutuhkan seperti informasi yang didapat dari petambak garam dan mendefinisikan sistem usulan yang akan dibuat oleh penulis dengan cara melihat kebutuhan masyarakat mengenai informasi produksi garam.

\section{Desain}

Pada tahapan ini deskripsi dari requirement yang telah direkomendasikan diubah ke dalam spesifikasi sistem physical dan logical. Dalam logical design hasil yang dapat adalah deskripsi fungsional mengenai data dan proses yang ada dalam sistem baru dan deskripsi yang detail dari spesifikasi sistem meliputi: input, proses, dan output. Sedangkan dalam physical design adalah deskripsi teknikal dan deskripsi yang detail dari spesifikasi sistem meliputi: programs, files, network, system software. Dengan UML (Unified Modeling Language) dan ERD (Entity Relationship Diagram) sebagai peralatan pendukungnya. Dalam tahapan ini penulis membuat spesifikasi input, proses dan output secara detail. Merancang program yang akan digunakan untuk mengetahui sistem informasi akademik sekolah ini yaitu dengan menggunakan website dan merancang user interface yang akan memakai sistem ini dan bagaimana sistem interface nya.

\section{Implementasi}

Tahapan ke empat dalam SDLC ini dimana dalam tahapan ini dilakukan beberapa hal yaitu coding, testing dan instalasi. Hasil dalam tahapan ini adalah source code dan prosedur pelatihan. Dalam kasus ini penulis membuat website dengan menggunakan php dan mysql untuk proses coding nya dan merancang atau membuat gambarnya dengan menggunakan adobe photoshop CS3.

\section{Pengumpulan Data 1. Observasi}

Merupaka metode yang dilakukan penulis dengan cara mendatangi langsung tempat riset yang ingin di teliti oleh penulis. Penulis melakukan pengamatan langsung di PT. Garam, Dinas Kelautan dan Perikanan kota dan kabupaten serta sentra garam indramayu, cirebon dengan beberapa acuan yaitu menganalisa beberapa dokumen yang terkait dengan produksi garam dan mengamati cara pembuatan garam.

\section{Wawancara}

Merupakan metode yang dilakukan penulis dengan cara melakukan tanya jawab secara langsung kepada nara sumber. Penulis melakukan tanya jawab dengan petambak garam dan operator pecatat produksi garam.

\section{Studi Pustaka}

Merupakan metode yang digunakan penulis sebagai pendukung dan referensi. Buku yang berhubungan dengan penelitian dan penulisan.

\section{HASIL DAN PEMBAHASAN Analisis Sistem Berjalan}

Analisis sistem bertujuan untuk mempelajari, menganalisis masalah dan memahami sistem yang ada sesuai dengan tujuan yang akan dicapai. Berdasarkan hasil pengamatan dan analisis yang dilakukan diketahui di Pusriskel belum ada sistem informasi prediksi produksi garam.

\section{Sistem Baru Yang Diusulkan}

Berdasarkan hasil analis permasalahan maka diusulkan sistem baru yang digambarkan secara lengkap dalam Diagram Use Case. Berikut Diagram Use Case sistem yang diusulkan Gambar 2.

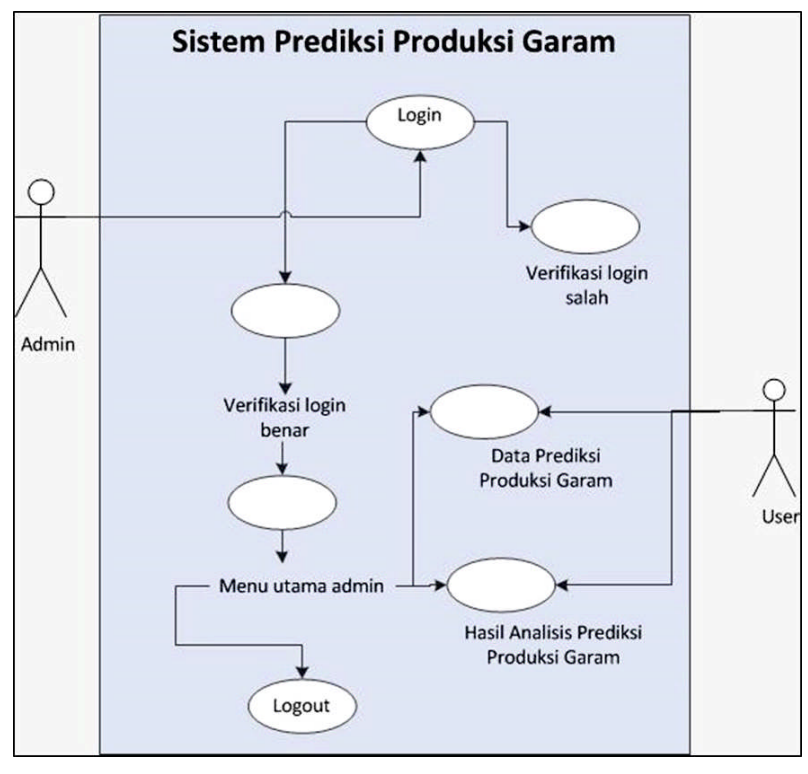

Gambar2. Diagram use case Sistem Prediksi Produksi Garam 
Tabel 1. Definisi Use Case

\begin{tabular}{|c|c|c|}
\hline No. & Use Case & Deskripsi \\
\hline 1. & Login & $\begin{array}{l}\text { Merupakan proses untuk melakukan login/masuk pengguna dari } \\
\text { sistem. }\end{array}$ \\
\hline 2. & Logout & $\begin{array}{l}\text { Merupakan proses untuk melakukan logout/keluar pengguna dari } \\
\text { sistem. }\end{array}$ \\
\hline 3. & Menu utama admin & $\begin{array}{l}\text { Halaman utama admin untuk megelola data dan hasil analisis } \\
\text { prediksi produksi garam }\end{array}$ \\
\hline 4. & $\begin{array}{l}\text { Halaman Data Prediksi } \\
\text { Produksi Garam }\end{array}$ & Mengelola Data Prediksi Produksi Garam \\
\hline 5. & $\begin{array}{l}\text { Halaman Hasil Analisis } \\
\text { Prediksi Produksi } \\
\text { Garam }\end{array}$ & Mengelola Hasil Analisis Prediksi Produksi Garam \\
\hline
\end{tabular}

\section{Perancangan Sistem}

Activity Diagram

Activity Diagram Pengolahan Data Prediksi Produksi Garam password terlebih dahulu jika tidak valid sistem akan menginformasikan kesalahan inputan dari user. Jika username dan password valid maka sistem akan otomatis kedalam halaman utama admin.

Pada activity diagram pengolahan data prediksi produksi garam admin memasukan username dan

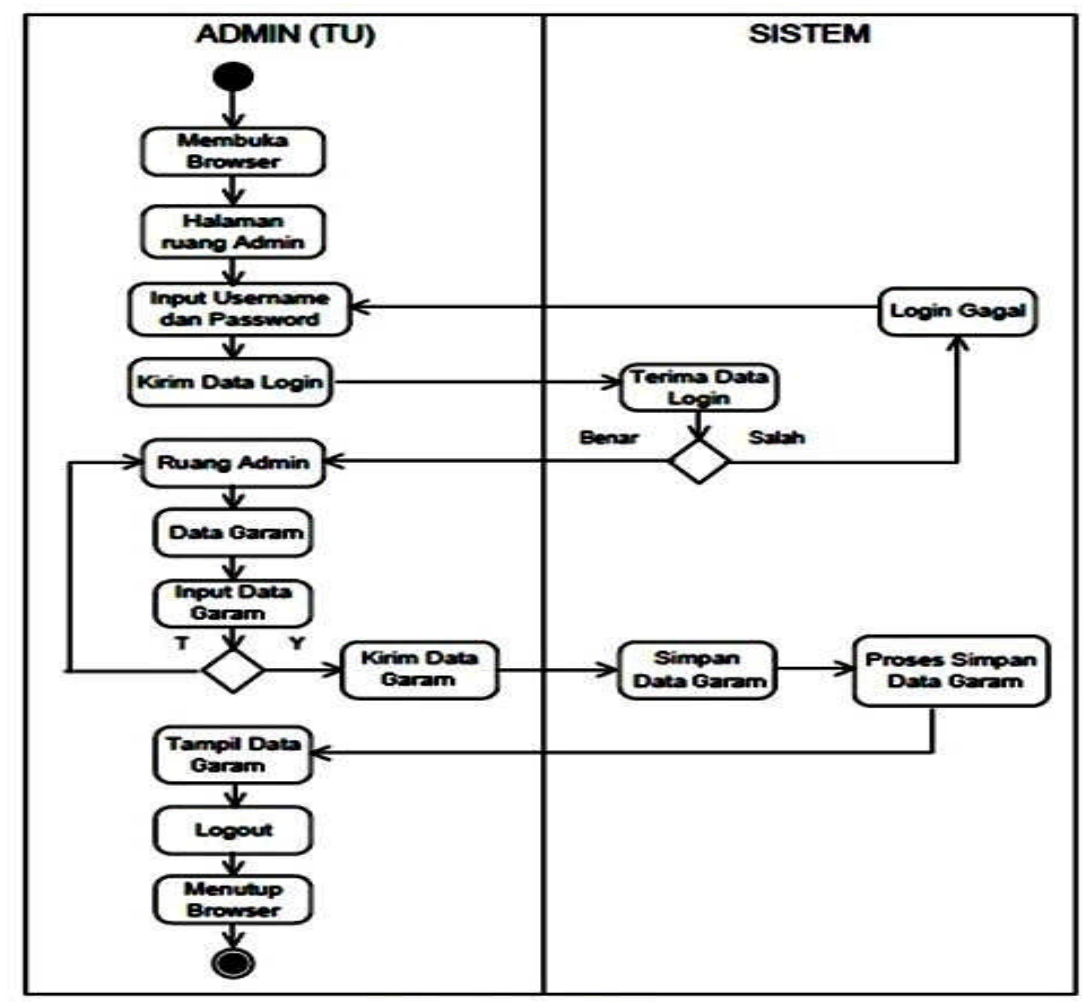

Gambar 3. Activity Diagram Pengelolaan Data Garam

\section{Perancangan Database}

Rancangan database dipakai untuk mempermudah dalam proses penyeleksian data, serta membantu pemprograman dalam mengambil dan menampilkan data. Pada database digunakan tabel-tabel, dan pada tabel-tabel ini akan dijelaskan nama field, type dan size mengenai data tersebut, dapat dilihat pada Gambar 4. 


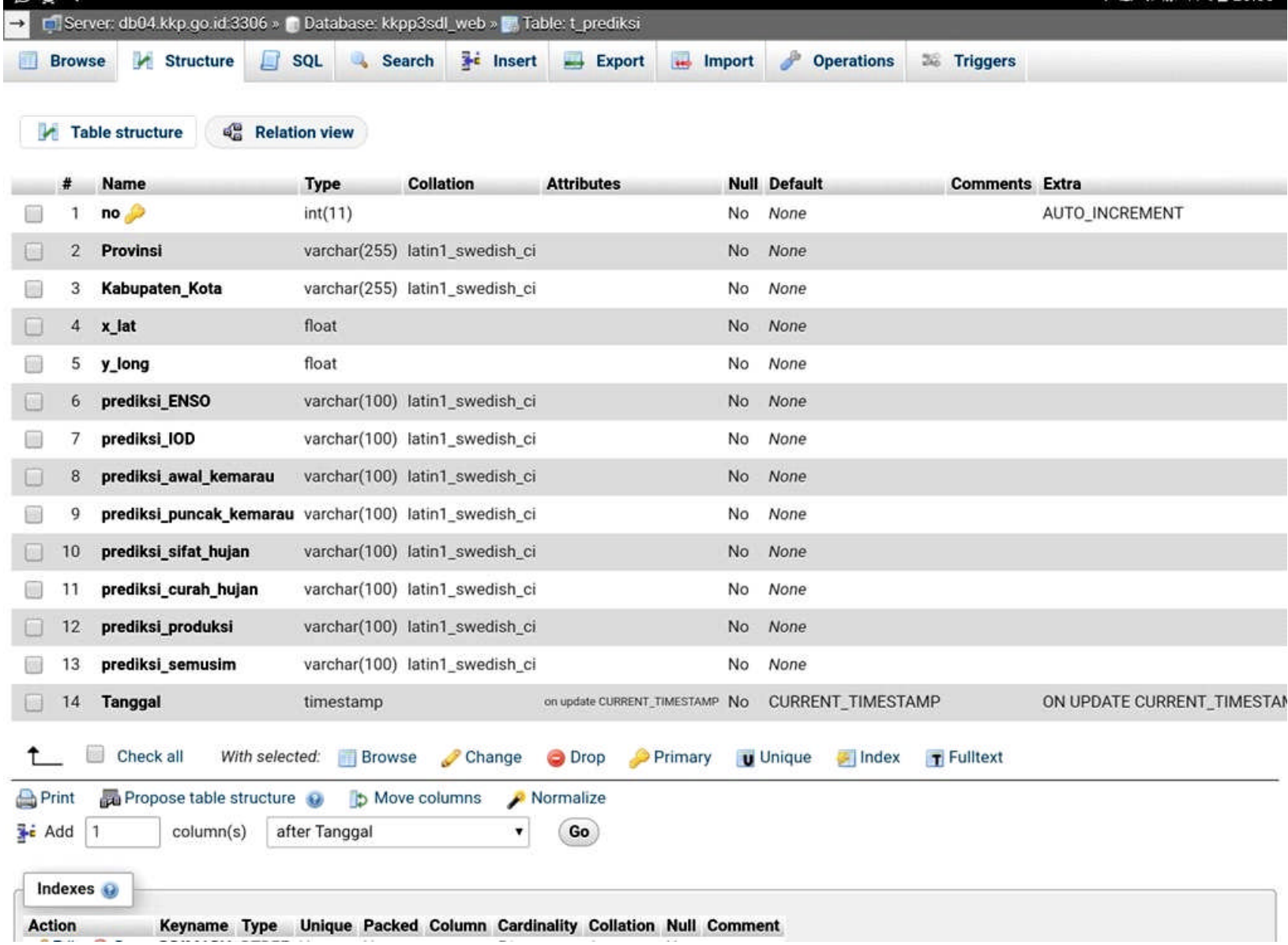

Gambar 4. Perancangan Database.

\section{Implementasi Perangkat Keras dan Perangkat Lunak \\ Perangkat Keras (Hardware)}

Perangkat keras yang digunakan untuk pembangunan aplikasi ini adalah sebuah komputer dengan spesifikasi:
a. Processor Intel(R) Core (TM) i5 CPU M520 @2.4 $\mathrm{GHz}$
b. Hardisk 320 GB 5400-rpm
c. RAM 2 GB
d. VGA Intel Graphics Media Accelerator (GMA) HD
e. LCD Monitor 14.1", 1280x800 pixels
f. Printer tinta sebagai alat pencetak output sistem yang berupa laporan (report) yang memiliki kemampuan untuk mencetak dengan ukuran kertas A4 dan F4.

Spesifikasi minimum penggunaan aplikasi ini dapat digunakan pada komputer yang memiliki minimum spesifikasi perangkat keras sebagai berikut:
a. Processor Intel Atom 1.8 GHZ
b. RAM $1 \mathrm{~GB}$
c. Hardisk $160 \mathrm{~GB}$

d. VGA Integrated

\section{Perangkat Lunak (Software)}

Piranti lunak yang digunakan pada pembangunan aplikasi ini:

a. Microsoft Windows 7 Professional Service Pack 1, 32 bit sebagai platform sistem operasi dalam pengembangan aplikasi

b. AMPP Web Server Version 1.7.3 sebagai webserver

c. MySQL Database Version 5.1.41 sebagai DBMS

d. phpMyAdmin Version 3.2.4 sebagai Database Manager.

e. Aplikasi Web Browser yaitu Firefox

f. Notepad ++ Version 6.6.1 sebagai text editor untuk coding (menuliskan source code PHP)

g. Aplikasi Dreamweaver

h. Aplikasi Microsoft Excel untuk menampilkan report.

i. Aplikasi Adobe Potoshop CS6 untuk mendesain tampilan aplikasi 


\section{Rancangan Tampila Website 1. Halaman Beranda}

Halaman beranda adalah halaman yang muncul pertama kali ketika user membuka website, Gambar 5.

\section{Halaman Prediksi Produksi Garam}

Halaman ini berfungsi untuk melihat prediksi produksi garam, dapat dilihat pada Gambar 6 di bawah ini.

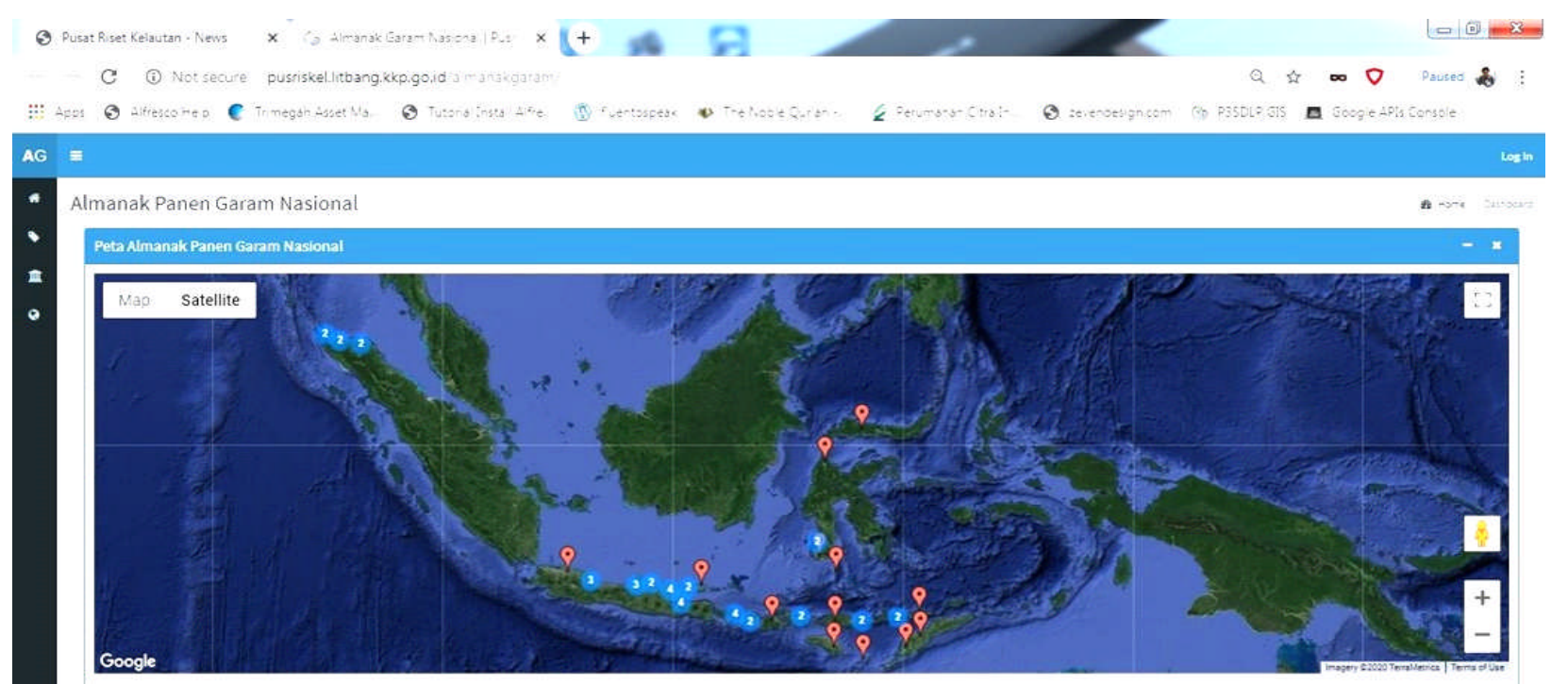

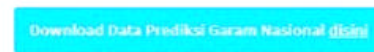

(4) 0 C

Gambar 5. Halaman Beranda.

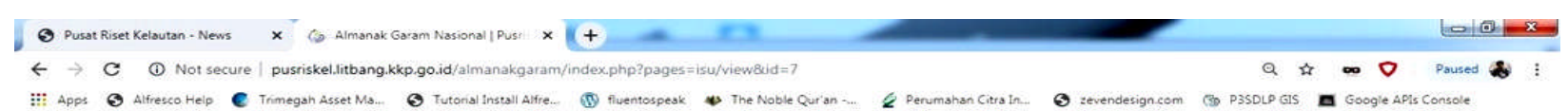

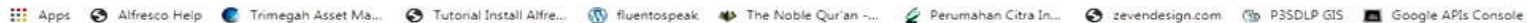

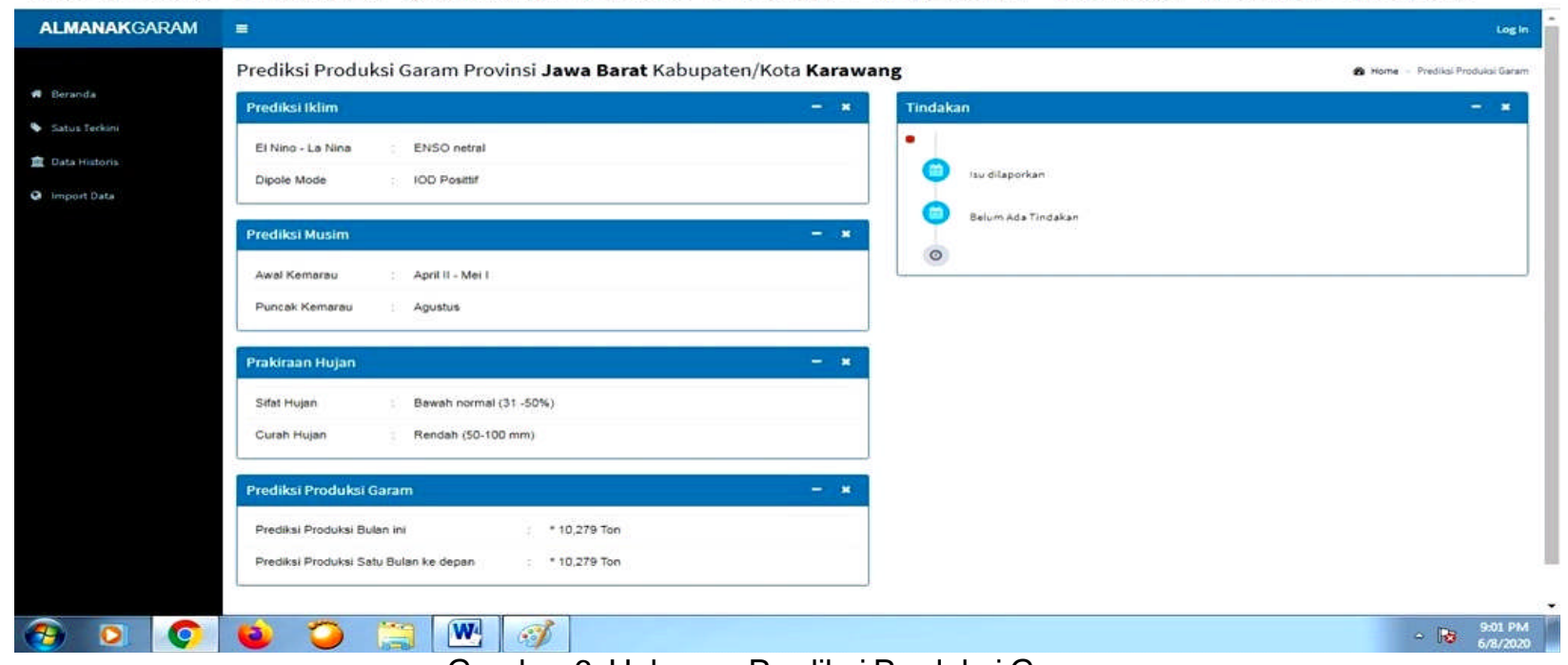

Gambar 6. Halaman Prediksi Produksi Garam. 


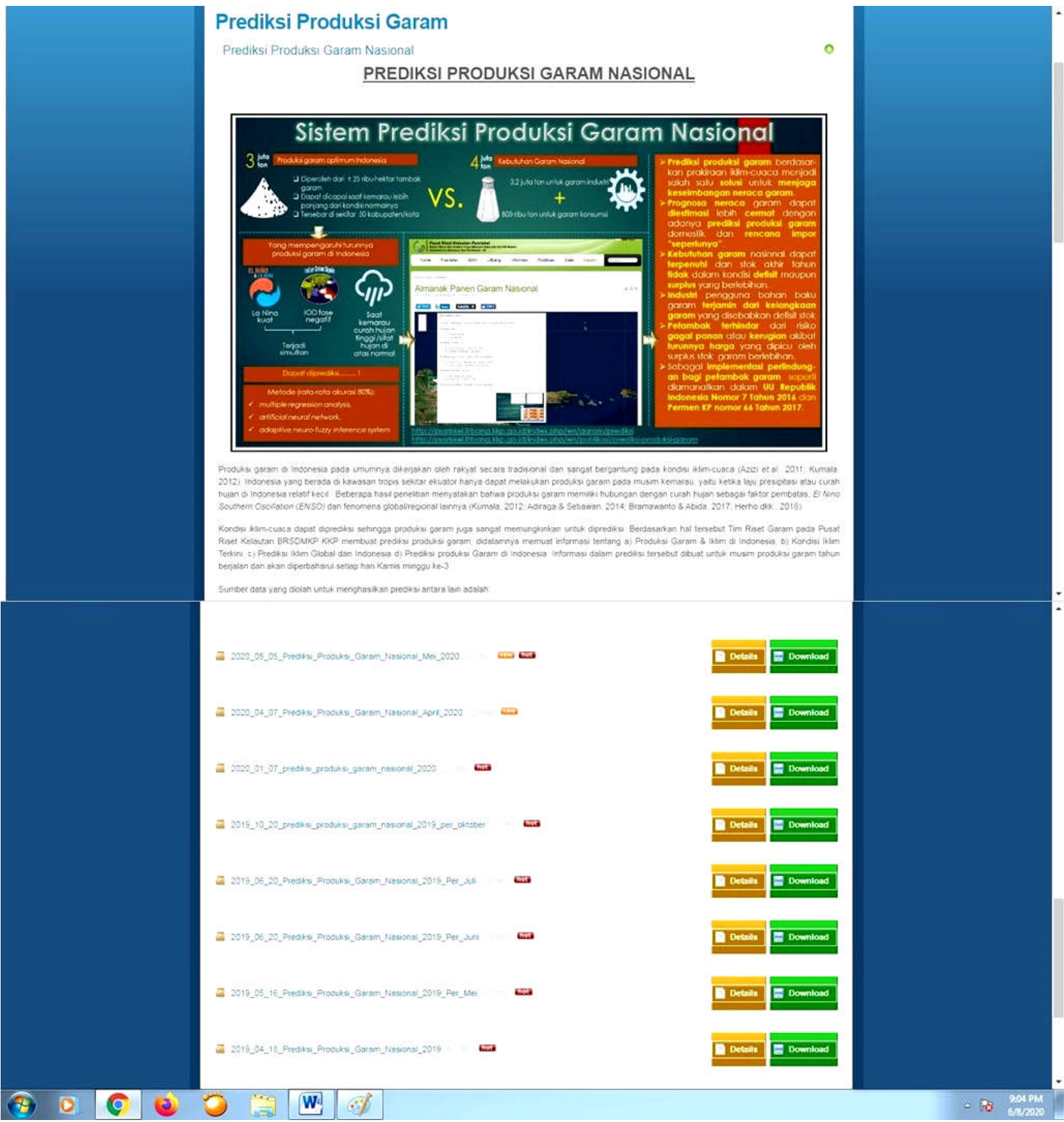

Gambar 7. Halaman Download Prediksi Produksi Garam.

\section{KESIMPULAN}

Berdasarkan hasil penelitian ini, maka dapat disimpulkan bahwa penggunaan sistem informasi prediksi produksi garam pada Pusat Riset Kelautan (Pusriskel) dapat memberikan solusi yang lebih cepat dalam pengolahan prediksi produksi garam, data garam bersifat time series, pembuatan laporan lebih efektif dan efisen karena penyimpanan data sudah dalam database.

\section{UCAPAN TERIMAKASIH}

Ucapan terima kasih penulis sampaikan kepada Pusat Riset Kelautan dengan kegiatan riset design system produksi sentra garam tahun anggaran 2019.

\section{DAFTAR PUSTAKA}

Buku Pintar jQuery dan PHP, Mediakom: 2011

Bunafit Nugroho, 2004, PHP dan MYSQL Dengan Editor Dreamweaver MX, Andi, Yogyakarta. 
Castillio G.C., Overbeek M. V., Bisilisin F. Y., 2015, Model Analisis Perkiraan Produksi Garam Di Kabupaten Kupang Menggunakan Metode Regresi Linear, STIKOM Uyelindo, Kupang.

Jogiyanto, HM. 2005. Analisis dan Desain Sistem Informasi. Yogyakarta. Andi.

Kadir, Abdul. 2004. Dasar Pemrograman Java ${ }^{\mathrm{TM}} 2$., Andi Offset., Yogyakarta.

Lenawati, Mei. 2007. Macromedia Dreamweaver 8 dengan PHP. Yogyakarta. Andi.

Peranginangin, Kasiman. 2006. Aplikasi Web dengan PHP dan MYSQL. Yogyakarta. Andi.

Roger, S. Pressman, Ph.D. , 2012, Rekayasa Perangkat Lunak (Pendekatan Praktisi) Edisi 7 :

Buku 1 ", Yogyakarta: Andi.

Rangkuti, F. 2004, Analisis SWOT Teknik Membedah Kasus Bisnis, PT. Graedia, Jakarta

Rosa, A.S. dan Salahuddin., 2013, Rekayasa Perangkat Lunak, Terstruktur dan Berorientasi Objek, Informatika: Bandung.
Saputra, A. 2013, Smarty, PHP OOP Engine for PHP Template, Elex Media Komputindo: Jakarta.

Yasin, V. 2012, Rekayasa Perangkat Lunak Berorientasi Objek, Pemodelan Arsitektur dan Perancangan (Modeling, Architecture and Design), Mitra Wacana Media: Jakarta.

Wiswakarma, K. 2010, Panduan Lengkap Menguasai Pemrograman CSS, Loko Media: Yogyakarta.

http://www.markijar.com/2015/04/kelebihan-dankekurangan-model-proses.html, 5 juni 2020

http://pusriskel.litbang.kkp.go.id/index.php, 6 juni 2020, 10:31

https://id.wikipedia.org/wiki/Surat, 19 April 2020 12:54

http://id.wikipedia.org/wiki/Web_server, 14 Mei 2020, 22:54

http://www.pengertianku.net/2015/09/pengertian-umldan-jenis-jenisnya-serta-contoh-diagramnya.html), 3 April $202011: 05$ 